\title{
Лесовозобновление и изменение растительного сообщества на вырубке подтаежных сосновых лесов Западного Хэнтэя Монголии
}

\section{Regeneration and change of plant community in the felling of subtaiga pine forest of Western Khentei, Mongolia}

\author{
Тушигмаа Ж. \\ Tushigmaa J. \\ Институт общей и экспериментальной биологии АН Монголии, г. Улан-Батор, Монголия. E-mail: tushig_j@yahoo.com \\ Institute of General and Experimental biology, MAS, Ulaanbaatar, Mongolia
}

Peфepam. Исследована вырубка в подтаежных сосняках на территории Западного Хэнтэя в Монголии. В рассматриваемых условиях через 37 лет после условно-сплошной рубки из сосняка разнотравно-брусничного формируется вейниково-разнотравное сообщество с подростом березы плосколистной и осины.

Ключевые слова. Береза, вырубка, лесовозобновление, Монголия, сосновый лес.

Summary. The felling in the subtaiga pine forests on the territory of Western Khentei in Mongolia was investigated. In the conditions under consideration, 37 years after the conditionally continuous felling of the pine of the herb-cowberry, the reed herb-Calamagrostis community is formed with the undergrowth of birch and aspen.

Key words. Birch, fell area, regeneration, Mongolia, pine forest.

\section{Введение}

Хэнтэй - один из основных лесных регионов Монголии, составляющий третью часть лесного фонда, где заготавливается почти половина всей древесины в стране. Основные и наиболее производительные массивы сосновых древостоев сосредоточены в западной части Хэнтэя. Интенсивные лесозаготовки и пожары здесь являются главными антропогенными факторами, оказывающими негативное влияние на состояние лесов, их средообразующие и почвозащитные функции. Интенсивная эксплуатация лесов, возникающие пожары, вредители и болезни существенно ухудшают санитарное состояние лесных сообществ, снижают их средообразующие и почвозащитные функции. На месте хвойных лесов часто формируются куртины мелколиственных древостоев, а на невозобновившихся вырубках формируется степная экосистема, что ведет к обезвоживанию малых рек и ручьев.

Большинство исследований рубок и пожаров в лесах Монголии посвящены оценке их влияния на лиственничные леса (Евдокименко, 1990; Дугаржав, 1996; Доржсурэн, 2009; и др.) Изучение сосновых лесов до недавного времени носило эпизодический характер и не отражало реального их состояния. Это послужило основным аргументом выбора направления наших исследований и определило их цель - изучить особенности естественного возобновления и изменения растительного сообщества после пожара и условно-сплошной рубки в подтаежных сосняках в районе Западного Хэнтэя Монголии.

\section{Материалы и методы}

Для решения поставленных задач на вырубках были заложены постоянные пробные площади (ППП). На ППП проводили описание и обмер деревьев методами, принятыми в лесной таксации (Молчанов, Смирнов, 1967; Анучин, 1982, Методы ..., 2002). Перечет деревьев на пробных площадях проводили по поколениям и породам.

Лесовозобновительные процессы древесных пород изучали по методикам (Побединский, 1966). Для этого на ППП в регулярном порядке закладывали учетные площадки размером 2 х 2 м в количестве 20 шт., на которых проводили учет подроста по видам, категориям и высотным группам. 
Учет и описание живого напочвенного покрова осуществляли в каждом квадрате 10 x 10 м на площадках размером $4 \mathrm{~m}^{2}$. При этом для каждого вида было определено проективное покрытие. При описании растительного покрова обилие видов определялось по шкале Друде с указанием проективного покрытия (Сукачев, Зонн, 1961). Названия видов растений даны по определителям сосудистых растений и мхов Монголии (Грубов, 1982; Цэгмид, 2001). Материалы исследований обрабатывали статистическими методами (Доржсурэн, 1992).

Анализ эколого-ценотического состава подчиненных ярусов осуществлен по эколого-ценотическим группам видов, при этом использованы разработки Т. Н. Буториной (1967) и С. А. Ильинской (1963). Нами было выделено четыре группы:

1. Тундрово-альпийские, к которым относили такие виды, как Aulacomnium palustre (Hedw.) Schwaegr., Cladonia arbuscula (Wallr.) Hale et C. Culb., Peltigera aphthosa (L.) Willd.

2. Таежные теневыносливые мезофиты, растущие в достаточно увлажненных местообитаниях.

3. Лесолуговые, к которым относятся мезофитные виды, растущие в умеренно увлажненных местообитаниях и не мирящиеся с сильным затенением.

4. Лесостепные и степные виды, к которым относили светолюбивые ксерофитные и мезоксерофитные виды, растущие в условиях недостаточного и временного недостаточного увлажнения.

\section{Результаты исследований}

В 2001 г. на условно-сплошной вырубке в осоково-разнотравном сосняке заложена ППП-6 площадью 0,25 га. Почва - горная, лесная, торфянистая (Баатар, Даваасурэн, 2007). Рубка древостоя проведена зимой 1976 г. с применением бессистемной тракторной трелевки хлыстов. В 1996 и 2003 гг. вырубка была пройдена низовыми пожарами.

В процессе исследований на вырубке было учтено 56 шт/га фаутных, поврежденных, отставших в росте и старых деревьев, а также 250 шт/га сильно обгоревших пней. Порубочные остатки были собраны в кучи. Кустарниковый ярус редкий, сформирован в основном Cotoneaster melanocarpa Lodd., Rosa acicularis Lindl., Spiraea media F. Schmidt.

На исследованной вырубке через 5 лет после последнего пожара было обнаружено преимущественно порослевое возобновление березы плосколистной и осины в возрасте от 5 до 13 лет. Общее количество подроста составляло 3875 шт./га. Высота подроста лиственных видов варьировала в пределах от 1,5 до 3,5 м (табл. 1).

Таблица 1

Характеристика полога подроста на осоково-разнотравной вырубке (над чертой) и в контрольном сосняке разнотравно-брусничном (под чертой)

\begin{tabular}{|c|c|c|c|c|}
\hline Вид & Плотность особей, экз. га & Встречаемость, \% & Возраст, лет & Высота, м \\
\hline \multirow{2}{*}{ Pinus sylvestris } & $=$ & $\overline{7}$ & $=$ & $=$ \\
& 2000 & 50 & $5-8$ & $0.1-0.5$ \\
\hline \multirow{2}{*}{ Betula platyphylla } & $\underline{1875}$ & $\underline{45}$ & $\underline{12-13}$ & $\frac{1,5-3,5}{12-13}$ \\
\hline \multirow{2}{*}{ Populus tremula } & $\underline{1500}$ & $\underline{45}$ & $\underline{5}$ & $\underline{5}$ \\
\hline
\end{tabular}

Примечание: прочерк означает отсутствие вида.

Подрост сосны был уничтожен во время рубки деревьев и трелевки хлыстов, а также низовыми пожарами. Послепожарных всходов или подроста сосны обыкновенной на вырубке не обнаружено. Первопричиной этого является интенсивное разрастание растительности нижних ярусов на вырубке при ослаблении конкуренции со стороны древостоя и формирование подстилки, которая часто препятствует проникновению семян сосны к минериальным горизонтам почвы и укоренению всходов в ней. Таким образом, на рассматриваемой паловой вырубке в Западном Хэнтэе сосна обыкновенная фактически не имеет возобновления, в то время как под пологом материнского древостоя на контрольной площади формируется подрост этого вида в количестве 2000 шт./га (табл. 1). 
Отсутствие возобновления сосны на паловой вырубке в Западном Хэнтэе связано, по-видимому, со слабой обсеменяемостью площади от стен леса и одиночно стоящих семенных деревьев, повышенной сухостью верхних горизонтов почвы, особенно подстилки, и интенсивным развитием растительности напочвенного покрова в условиях существенного снижения конкуренции в зоне корневых систем.

Среднее проективное покрытие травяно-кустарничкового яруса составляет 57 \%, преобладают Iris ruthenica Ker-Gawl., Rubus saxatilis L., Allium victorialis L., Thalictrum minus Lindl., Carex pediformis C. А. Меу. Под пологом леса в контроле общее проективное покрытие травяно-кустарничкового яруса составляет 52 \%, доминируют Vaccinium vitis-idaea L., Linnaea borealis L., Maianthemum bifolium (L.) F. Shcmidt, Allium victorialis L.. Удаление древесного яруса и последующие пожары на условно-сплошной вырубке стали причиной уменьшения встречаемости и проективного покрытия таких таежных лесных видов, как Pyrola incarnata (DC.) Freyn, Maianthemum bifolium L., Vaccinium vitis-idaea L. При этом зафиксировано увеличение видового разнообразия лесолуговых, степных и лесостепных видов: Rosa acicularis Lindl., Iris ruthenica Ker-Gawl., Thalictrum minus L., Chamaenerion angustifolium (L.) Scop., Elymus sibiricus (L.), Carex pediformis C. A. Mey., Bromus pumpellianus Scribn. Из прежнего состава полностью выпали тундрово-альпийские и таежные виды, такие как Aulacomnium palustre (Hedw.) Schwaegr., Cladonia arbuscula (Wallr.) Hale et C. Culb., Peltigera aphtosa (L.) Willd, Rhododendron dahiricum L., Ledum palustre L., Lonicera altaica Pall., Linnaea borealis L., Hylocomium splendens (Hedw.) B. S. G., Pleurozium schreberi (Brid.) Mitt.

Под пологом сосняка разнотравно-брусничного общее число видов практически равно таковому на осоково-разнотравной вырубке, однако соотношение эколого-ценотических групп различается (табл. 2). В первом сообществе в составе напочвенного покрова присутствуют в небольшом количестве тундрово-альпийские виды (с проективным покрытием 5 \%), которые полностью отсутствуют во втором сообществе; под пологом леса доля таежных видов в 1,7 раза больше, а доля лесолуговых, лесостепных и степных видов $(31,7$ \%) примерно в 1,5 раза выше, чем на вырубке, а доля лесолуговых и лесостепных видов почти в 1,5 раза меньше, чем на вырубке.

Таблица 2

Распределение растений по эколого-ценотическим группам в исследованных сообществах

\begin{tabular}{|c|c|c|c|c|}
\hline \multirow{2}{*}{$\begin{array}{c}\text { Эколого-ценотическая } \\
\text { группа }\end{array}$} & \multicolumn{2}{|c|}{$\begin{array}{c}\text { Сосняк разнотравно-брусничный } \\
\text { (ППП-1) }\end{array}$} & \multicolumn{2}{|c|}{$\begin{array}{c}\text { Осоково-разнотравная вырубка } \\
\text { (ППП-6) }\end{array}$} \\
\hline & Число видов & $\begin{array}{l}\text { Проективное по- } \\
\text { крытие, \% }\end{array}$ & Число видов & $\begin{array}{l}\text { Проективное } \\
\text { покрытие, \% }\end{array}$ \\
\hline В целом & 60 & 100 & 59 & 100 \\
\hline В том числе: & & & & \\
\hline тундрово-альпийские & 3 & 5,0 & - & - \\
\hline таежные & 19 & 31,7 & 11 & 18,6 \\
\hline лесолуговые & 31 & 51,7 & 38 & 64,4 \\
\hline степные и лесостепные & 7 & 11,6 & 10 & 17,0 \\
\hline
\end{tabular}

Коэффициент сходства с лесным сообществом по видовому составу составляет 62 \%, по ценотической значимости - 39 \%. Наличие в составе напочвенного покрова вырубки таких видов степной и лесостепной группы как Carex pediformis C. А. Меу. является, возможно, дополнительным фактором, затрудняющим возобновление сосны.

Таким образом, анализ полученных данных выявил, что в рассматриваемых условиях через 32 года после условно-сплошной рубки сосняка разнотравно-брусничного на фоне повторяющихся с интервалом 5-12 лет низовых пожаров формируется осоково-разнотравное сообщество с подростом березы плосколистной и осины. Кроме того, на вырубке процесс восстановления напочвенного покрова после пожара имеет ряд отличий от его восстановления после низового пожара под пологом леса.

На исследованной вырубке через 37 лет после рубки наблюдениями установлено, что позиции рыхлокустовых и корневищных злаков на рассматриваемом участке продолжают укрепляться, особенно разрастается Calamagrostis obtusata Trin. и Carex pediformis C. A. Меу. Среднее проективное покры- 
тие травяно-кустарничкового яруса достигает 49,5 \%. При этом зафиксировано увеличение видового разнообразия лесолуговых, степных и лесостепных видов: Iris ruthenica Ker-Gawl., Thalictrum minus L., Rubus saxatilis L., Calamagrostis obtusata Trin., Chamaenerion angustifolium (L.) Scop., Carex pediformis C. A. Mey.

Проведенные исследования позволяют отметить, что восстанавливающийся напочвенный покров на 37-летней вырубке имеет ряд отличий от напочвенного покрова под пологом леса на контрольной ППП-1: коэффициент сходства с лесным сообществом по видовому составу составляет $57,4 \%$, по ценотической значимости $-41,8$ \%. Наличие в составе напочвенного покрова вырубки таких видов лесостепной и степной группы, как Calamagrostis obtusata, Carex pediformis является, на наш взгляд, дополнительным фактором, затрудняющим возобновление сосны обыкновенной.

\section{Заключение}

В рассматриваемых условиях через 37 лет после условно-сплошной рубки сосняка разнотравно-брусничного формируется вейниково-разнотравное сообщество с подростом березы плосколистной и осины.

\section{ЛИТЕРАТУРА}

Анучин П. Н. Лесная таксация. 5-е изд. - М.: Лесн. пром-сть, 1982. -550 с.

Баäap P., Даваасурэн Д. Некоторые итоги исследования свойства почвенного покрова окрестности лесного стационара Шарынгол // Тр. Института Ботаники АНМ, УБ, 2007. - № 17. - С. 82-86.

Буторина T. Н. Эколого-ценотический анализ кустарничково-травяного яруса лесных ассоциаций // Типы лесов Сибири, 1967. - С. 3-95.

Грубов В. И. Определитель сосудистых растений Монголии (с атласом). - Л.: Наука, 1982. - 442 с.

Доржссурэн Ч. Программа обработки материалов растительного покрова постоянной пробной площади исследования // Межинститутский науч.-исслед. сб. тр., 1992. - № 1. - С. 16-19.

Доржссурэн Ч. Антропогенные сукцессии в лиственничных лесах Монголии //Биологические ресурсы и природные условия Монголии: Тр. Совместной Российско-Монгольской комплексной биологической экспедиции. M.: 2009. - T. 50.- $260 \mathrm{c}$.

Дугаржсав Ч. Лиственничные леса Монголии (Современное состояние и воспроизводства): Автореф. дисс. ... доктора биол. наук. - Красноярск, 1996. - 59 с.

Eвдокименко М. Д. Пирогенная деструкция лиственничных лесов // Экология и природопользование в Монголии. УБ.: 1990. - С. 83-85.

Ильинская С. А. Изучение синузиальной структуры лесных сообществ // Типы лесов Сибири. - М.: Наука, 1963. - C. 5-29.

Методы изучения лесных сообществ. - СПб.: НИИХимии СПбГУ, 2002. - М54. - С. 67-73.

Молчанов А. А., Смирнов В. В. Методика изучения прироста древесных растений. - М.: Наука, 1967. - С. 3-95.

Побединский А. В. Изучение лесовосстановительных процессов. - М.: Наука, 1966. - С. 1-63.

Сукачев В. Н., Зонн $\boldsymbol{C . ~ В . ~ М е т о д и ч е с к и е ~ у к а з а н и я ~ к ~ и з у ч е н и ю ~ т и п о в ~ л е с а . ~ - ~ М . : ~ И з д - в о ~ А Н ~ С С С Р , ~ 1 9 6 1 . ~ - ~} 144$ с. Цэгмид Ц. Определитель мхов Монголии. - УБ.: Соёмбопринтинг, 2001. - 473 с. 